\title{
Reconsidering the contents of interpreters' notes: A human-centered approach to classification
}

\author{
Anna Sasaki \\ Seisen University, Waseda University, Tokyo \\ m@dranna.net
}

\begin{abstract}
This paper tackles the issue of the lack of a substantially new approach to classifying the interpreters' notes. In my paper, I highlight the fact that the researchers in the field are yet to agree on the contents of interpreters' notes, and that is, in my opinion, the problem that is numerously stumbled upon in consecutive interpretation research in general and note-taking research in particular. Not only do researchers invent new classifications within an excising paradigm, sometimes they contradict each other presenting different definitions for the same concepts. This paper attempts to solve the issue by introducing a new perspective on the contents of interpreters' notes by adapting the human-centered approach and turning to the "writers" of the notes, the interpreters. The interpreter trainees who participated in this research were interviewed to obtain an in-depth understanding of what is included in interpreters' notes. Under the semiotic perspective, which assumes both linguistic and non-linguistic notes as a system of signs, I classified the interpreters' notes based on the subject's comments to the notes they had written. This retrospective approach unveiled how interpreter trainees perceive their notes which prompt meaning-making and facilitate the memory when delivering interpretation.
\end{abstract}

Keywords: consecutive interpretation, interpreters' notes, semiotics.

\section{Introduction}

The present research aims to show the difference between how a researcher perceives the interpreters' notes and how the interpreter themselves perceive their writing. By doing so this paper aims to attract attention to the necessity of more thorough research in this domain and offers some of the possible solutions in its conclusions.

The contents of interpreter's notes, hand in hand with the choice of notation language, might be the most controversial issues in note-taking research. 
The language used in interpreters' notes is considered one of the factors, along with the teaching method, the working memory, and the background knowledge, of successful interpretation by many researchers (e.g., Alexieva 1993; Gile 2005; Ilg 1989). At the same time, some scholars think that "if words, symbols or abbreviations written down are understood just as symbolic cues for ideas that have already been understood, the language they are drawn from is irrelevant" (Dawrant \& Setton 2016: 115). This controversial disagreement reveals the difference in understanding how interpreters' notes should look like.

For example, the question of whether or not the language used in interpreters' notes serves as a factor for a successful interpretation reveals the different viewpoints on the contents of interpreters' notes. The most common answer to this question is "yes": "Interpreters decide on a case-by-case basis which language code ... to use when writing down understood contents in their notes" (Someya 2017: 170). Presently, one of the most common research topics to the language used in interpreters' notes is the use of a language in the notes under a case-by-case decision made by the interpreter influenced by certain factors (Albl-Mikasa 2017; Dam 2004).

Those who advocate for "no" doubt if the language used for interpreters' notes are at all relevant as a factor that influences production (Dawrant and Setton 2016; Jones 2002). The reason for these doubts lies in MinyarBeloruchev's (1969), Matyssek's (1989) and later Albl-Mikasa's (2017) research, in which the interpreters' notes were investigated from a semiotic viewpoint. The early research argues that the notes are the system of symbols, rather than linguistic elements, which brings us to the conclusion that the question of the inability of solving the language choice problem in note-taking without a careful and thorough examination of the contents of interpreter's notes.

The issue of the use of a language in interpreters' notes is discussed in the context of the source and target language interaction in the interpreter's mind during speech comprehension and reproduction, which leaves neglected the question of symbolic contents of interpreter's notes. However, the disagreement on the question of the language used in interpreters' notes sheds light on different viewpoints concerning the contents of interpreters' notes. Figuratively speaking, the language in interpreters' notes research turns into a swamp because of the inability of researchers to agree on the contents of interpreters' notes. Below is a brief overview of some different viewpoints theorizing the interpreters' notes. 


\section{Interpreters' notes: diversity of research perspectives}

For starters, terms such as "notes", "note-taking in consecutive interpretation", "interpreters' notes" or "brief note-taking" and "notation", "notizentechnilc fur dolmetscher" are used in the English and German studies, the term used by French researchers (Herbert 1952, Rozan 1956, Seleskovitch 1986) "la prise de notes" (memos, conspectus, notes for memory) means noting the main points of what was read or heard in a very broad sense. This term (la prise de notes) can be found in many modern French textbooks on language learning used with a different meaning from that in the note-taking research (Crèpin and Loridon 1992). In Japanese research, Komatsu uses the term "notes" ( 一ト), while other researchers (e.g. Someya 2017, Komatsu 2005) specify their subject as "interpretation notes" (通訳ノート). The Russian research contributes to the term "interpreters' stenography" (perevodcheskaya stenografiya), which highlights interpreters' notes as an encoding tool. These definitions approach their subject from different perspectives. The number of different definitions in the same category also emphasizes that the researchers do not have a single viewpoint on interpreters' notes; see Figure 1.

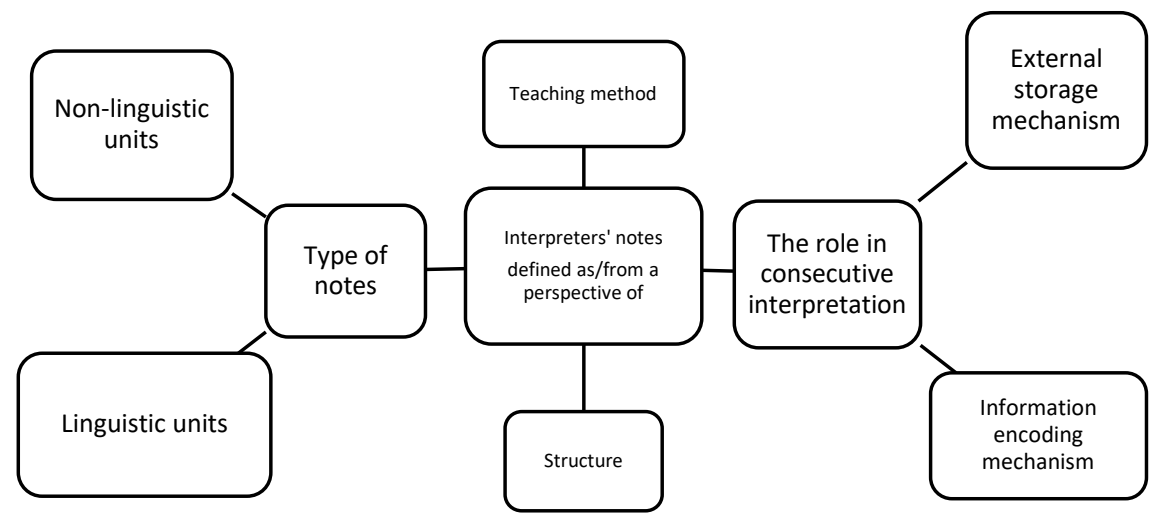

Figure 1. Categories of interpreters' notes definitions.

In order to introduce these diverse perspectives, I classified the definitions of interpreters' notes into four categories, some of which also include sub- 
categories, presented in Figure 1. Despite each category and subcategory deserves a separate rendition, this paper will only cover "the types of notes" category and its subcategories as essential for its argument.

Theorized as the types of notes, the interpreters' notes present a viewpoint of the job-oriented encoding tool. The interpreters' notes should be written in a way that will trigger the memory and allow the interpreter to use it as a speech reproduction tool. Gillies (2005: 109) writes that structure of the interpreters' notes can help recall information, which seems a fair statement in the context of an explanation given in the previous subsection: "The very presence of the structural element in your notes may remind you of all information to which it referred". However, the structure alone does not provide the accurate recall: "Memory can do much more than this if it is given the right prompts" (Gillies 2005: 109). By referring to notes as "memory prompts", Gillies hints on the encoding mechanism function of the interpreters' notes. As was said earlier, the interpreter notes the concepts, so conventional ways of writing are counterproductive. On the other hand, the notes are argued to reflect the interpreter's analysis of the source speech and to become the prompt that will serve as a base of target speech reproduction.

The first and most common viewpoint is that the interpreters should resort to language-based units (e.g. Dawrant \& Setton 2016; Gile 2005; Gillies 2005; Jones 2002; Herbert 1952; Rozan 1956). The second viewpoint is that the interpreters should take notes using different symbols (Matyssek 1989; MinyarBeloruchev 1980). The question on what types of interpreters' notes exist and how to classify them reveals the difference of researcher's viewpoints on the role of the interpreters' notes and their function in consecutive interpretation.

The first note-taking textbooks classified interpreters' notes as words and symbols. Herbert and Rozan's approach was based on using mainly words and some 20 recommended symbols. In 1950s interpreters' notes were still considered as an individual notation tool that can be used but is not necessary for consecutive interpretation. The publication of the first note-taking textbooks provided a new understanding of the role and functions of the interpreters' notes in consecutive interpretation. As a result of reconsidering the role functions of interpreters' notes, a new approach emerged. Opposed to Rozan's technique, Russian researcher Minyar-Beloruchev (1980) opted for more symbols in interpreters' notes to avoid interference from the source language notes during target speech production. Minyar-Beloruchev described note-taking as a stenography. The note-taking options proposed by Minyar-Beloruchev included both symbols and short-hand writings. The researcher proposed that 
interpreters' notes themselves could be considered as a special kind of writing system and he taught his students the principals of encoding with the use of this writing system. The advantage of this method was argued to be the creation of notes that could be read at any moment by any interpreter who knows the writing system. Unlike the individual notes that generally could be read by only the interpreter who wrote them and only during the interpretation of a speech fragment, Minyar-Beloruchev's notes were supposed to be a unified tool of any interpreter in any country working with any language. His language-independent approach based on the use of symbols to represent concepts was further picked up and developed by Matyssek (1989), who proposed a system of combinatory symbols. Matyssek along with Minyar-Beloruchev are criticised for their exhaustive collection of symbols in present-day research (Gillies 2005; Johnes 2002). The majority of the interpreter's autobiographical essays, however, advocate for the use of symbols in their notes:

\footnotetext{
One major advantage of employing ideograms [symbols] in notation is that they immediately cancel out actual words used in the source language to describe that concept. Not having the words used by the speaker on paper eliminates the danger of trying to use the same words in the target language, especially when the interpreter is tired at the end of a long day (Obst 2010: 33)
}

Obst illustrates this passage with an example of the interpretation of the word "demonstration" in the phrase "yesterday, there was a demonstration in front of the White House" into French (2010: 33). He writes that looking at the word "demonstration" a tired interpreter would use it as it is in French because this word exists in the French language. However, considering the context, the correct translation is "manifestation". "Working form an ideogram, an interpreter who is fluent in French would never make that mistake", concludes Obst (2010: 33). Professional interpreters should know their symbols so well that they automatically flow onto the paper as soon as the corresponding concept is drawn from the fragment of the source speech.

Nevertheless, even if the interpreter uses a lot of symbols they cannot avoid using language-based units in their notes. Most of the time these words are abbreviated, shortened or paraphrased. The later research (Gile 2005; Seleskovitch 1986) argued that interpreters note down the concepts and that interpreters' notes themselves are a symbolic representation of the concepts in interpreters' mind. In response to the appearance of new viewpoints, what was called words in the early research was described as abbreviations, shortenings, 
and paraphrase. In the 21st century, the research on note-taking has been published not only in European languages (English, French, German) but also in Asian languages, such as Chinese or Japanese (e.g. Komatsu 2005; Liu 2009; Dawrant \& Setton 2016). The different types of languages and writing systems contributed to additional note-taking options.

Generally speaking, the various approaches in the early and present-day studies do not differ that much with regard to basic principles on note-taking (Ahrens 2005b). With no substantially new teaching method, the researchers chose to expand the existing practices by introducing numerous note-taking options. This resulted in the appearance of note-taking recommendations, some of which are barely applicable to note-taking in different language combinations and some of which point in different directions. For example, in one of the most recent works of pedagogical character by Dawrant and Setton an arrow pointing right $(\rightarrow)$ symbol is presented with the definition of a "starting point" and "result" at the same time (Dawrant \& Setton 2016: 165). In Gillies's textbook, the same symbol is defined as "reason" (Gillies 2005:106). Being a Chinese interpreter, Setton introduces characters as one of the strategies of note-taking. For example, a character 人 (human) is described as a substitute for the word "person" in such words as "businessman" (bus 人) or "rural residents" (rur 人), etc. (Dawrant \& Setton 2016: 162). However novice this recommendation may seem, they will probably not be of use by those interpreters who do not work with Asian languages.

To give a clear illustration on the different types of interpreters' notes in the large volume of literature on note-taking generated over the years, the present article calculated the number of mentions of different note-taking options given in the definitions and examples of eight English-language textbooks on note-taking produced by Dawrant \& Setton (2016), Chernov (2004), Gile (2005), Gillies (2005), Jones (2002), Komatsu (2005), Liu (2009), Someya (2017), Taylor-Bouladon et. al. (2001) in the interval between years 2002 and 2017. These works were chosen as they are the most recent paper cover literature on note-taking in consecutive interpretation. There are many articles with new descriptions of linguistic and non-linguistic units in the notes published every year, but these articles are not of a pedagogical character. Figures 2 and 3 below illustrate the number of times a certain note-taking technique is mentioned in all the books. Most of these techniques are introduced with an example. The calculation included all the examples which demonstrated a certain note-taking technique in different textbooks. 


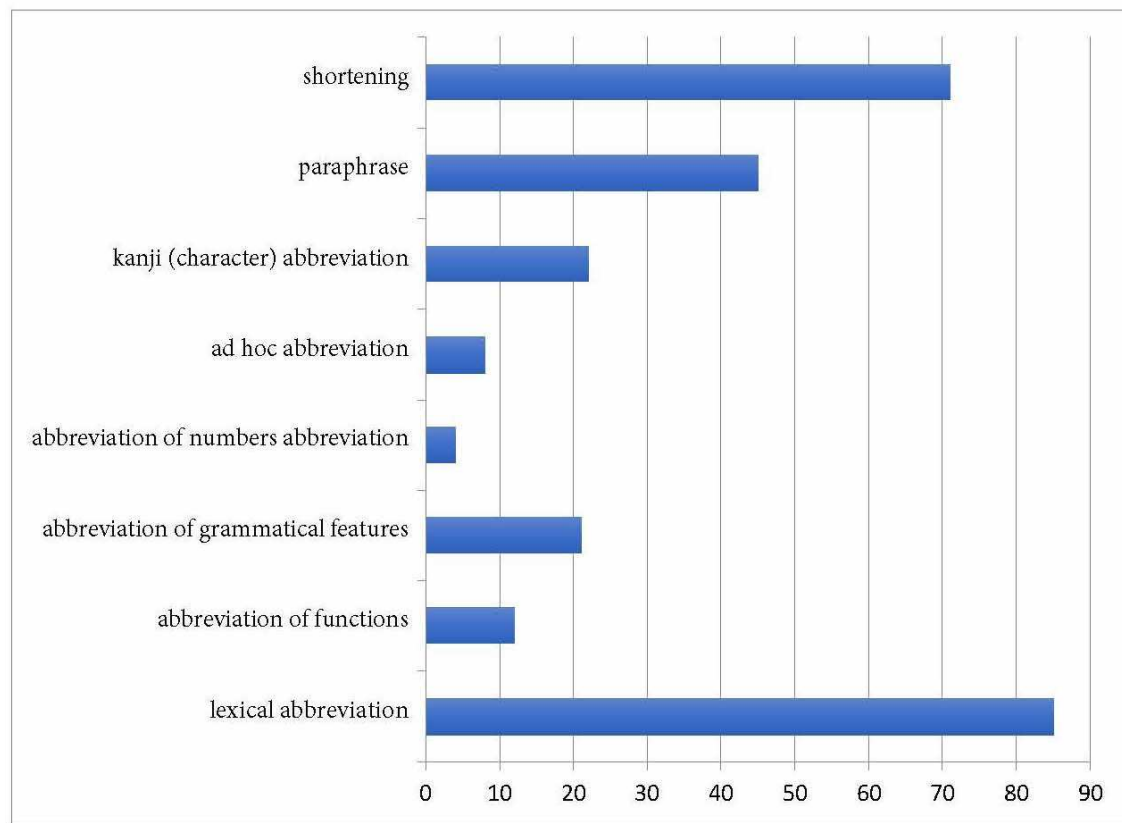

Figure 2. The number of mentions of different linguistic units in research literature.

Figure 2 shows that apart from shortening and paraphrasing there are different viewpoints on the types of abbreviations of interpreters' notes. Shortening and paraphrasing are widely discussed in Gile's (2005), Gillies's (2005) and Dawrant and Setton's (2016) textbooks as language-based notation units that compared with the source or the target speech are either shortened or paraphrased based on the exciting rules of either the source or the target language. The different kinds of abbreviations are introduced mainly in Dawrant and Setton's work. Apart from the abbreviation, they distinguish ad hoc abbreviation, kanji abbreviation, abbreviation of numbers and grammatical features, abbreviation of functions. "Abbreviation" - in their understanding - "includes devices for abbreviation words, phrases, numbers [...]. Words and phrases can be abbreviated using existing standard forms in current use, or ad hoc by applying certain principals" (Dawrant \& Setton 2016: 161). The focus of Dawrant and Setton's work on abbreviation is mostly because the mixture of European and Asian languages in their viewpoint allows for more creative notes 
with the use of iconicity that is a distinctive feature of Asian language writing systems.

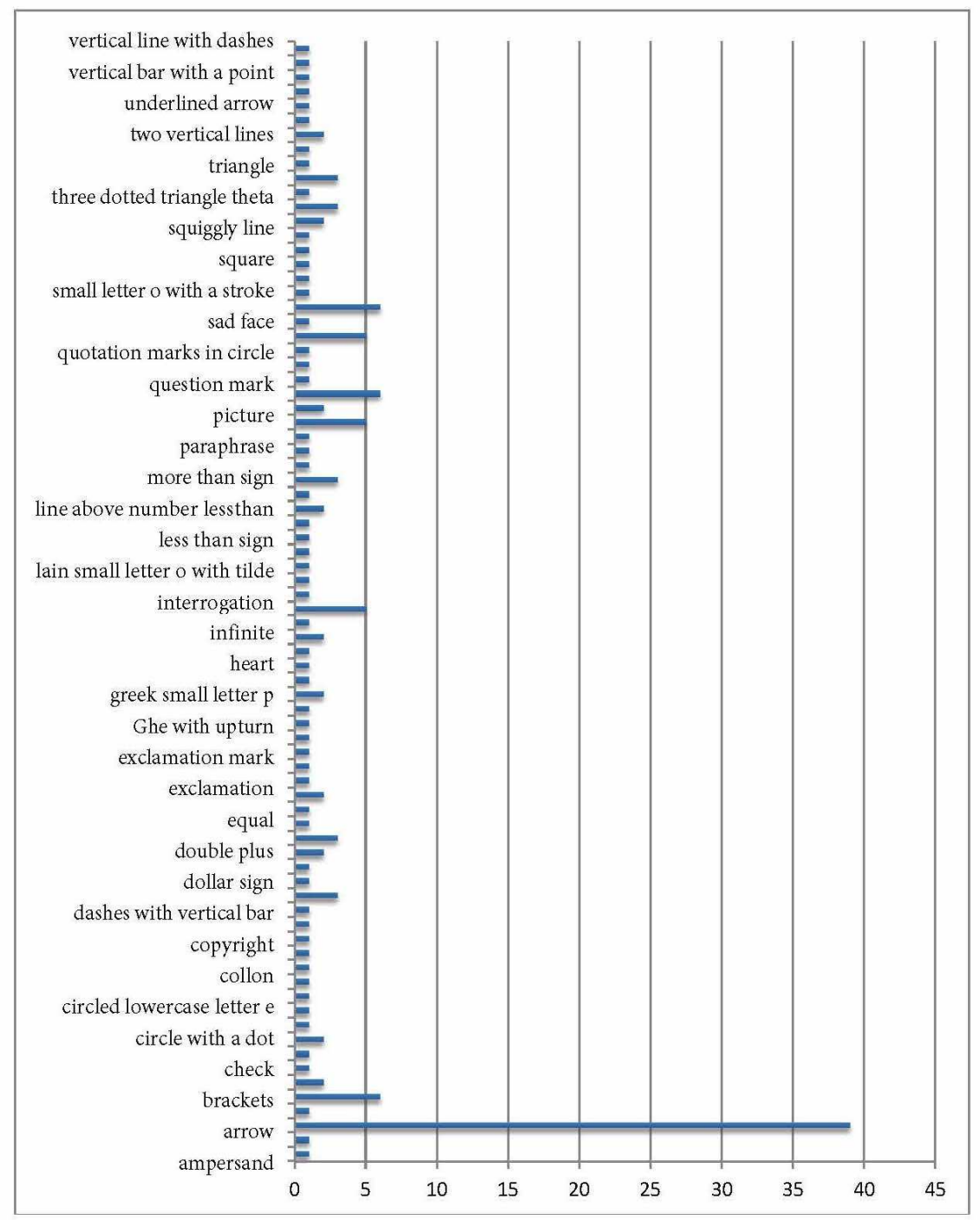

Figure 3. Number of mentions of different non-linguistic units in research literature. 
Comparing to some misconceptions in the linguistic types of notes shown in Figure 2, Figure 3 highlights the dispute with the symbols in the interpreters' notes. At first glance, it is clear that the number of symbols that were only mentioned once in a single textbook and were not mentioned in any other textbooks is extremely high. It is fair to say that interpreters are expected to customize the existing practices in their notes. However, it seems that most of the present-day teaching material reports those customized options as a basic system for note-taking in consecutive interpretation. The present-day literature on consecutive interpretation is criticized for a majority of empirically unproven personal experience-based research (Dam 2004; Szabo 2006).

Moreover, the terms the researchers introduce in their training and research materials may contradict one another. On one hand, many of them report that the interpreters' notes include the full words, or "the language" in Chen's research (2017), along with abbreviations, shortening, and paraphrases (e.g., Alexieva 1993; Gile 1995; Ilg 1989). On the other hand, interpreter-training literature does not often explicitly acknowledge full words as one of the units of interpreters' notes (e.g., Gillies 2005). According to Dawrant and Setton (2016), the full words in the interpreters' notes are where meaning is drawn from. By considering the full words as the contents of the interpreters' notes the researchers implicitly point out that the notes contain the units of both linguistic and symbolic nature: "Interpreters' notes can be either (literal) chunks taken from the surface structure, or sign and symbols" (Albl-Mikasa 2017: 72).

Another difference in viewpoints was despite having a substantial amount of controversial descriptions many researchers introduce their descriptions in their research papers:

The note categories and their definitions are specified in [...], following the rules specified in Dam (2004). Dam's rules catered to Danish and Spanish, so adaptations were made where necessary to account for the language combinations of Chinese and English. For example, Chinese characters with very simple strokes are sometimes used by interpreters as symbols. (Chen 2017: 10)

This example illustrates that to carry out research on language choice in interpreters' notes a researcher has to come up with the terminology that fits the language pair they are working with. Sometimes it is done with little reference to empirical evidence to support their choice of categories. Much of the literature on interpreters' notes is prescriptive, and there is little descriptive 
evidence of what interprets do in note-taking and the reasons behind it. Therefore, to shed light on such and similar questions a theoretical boundary between a symbol and a linguistic unit in interpreters' notes should be drawn.

\section{Theorizing a boundary between a symbol and a linguistic unit in interpreters' notes}

The way the interpreters' notes are encoded is said to play a vital part in the interpreting process. For example, Dam (2007: 190) discusses a "correlation between target-text inaccuracy and a relatively high proportion of full words and a smaller quantity of abbreviations". The interpreters are said to note "ideas", rather than words themselves (Gillies 2005). The interpreters' notes usually consist of abbreviations, symbols, paraphrases, shortenings, structuring signs like arrows, brackets, circles. These signs represent the cues that an interpreter fishes out of a more detailed source speech. Seleskovitch (1986) writes about the process of deverbalisation, or conceptualisation, in which the interpreter detaches themselves from the actual words and word combinations and operates with concepts.

A large portion of research on note-taking describes interpreters' notes as a system of individual and general principles, types, techniques, symbols, each of them is an encoded unit which is used by the interpreter in the course of consecutive interpretation:

The interpreter's notes will mostly not be 'in' this or that language. They will contain symbols and abbreviations, words from two or even more languages, and will be in a cryptic form - the diagonal layout with a left-hand margin reserved for specific purposes - with does not refer to the grammar and syntax of any particular language.

(Jones 2002: 60)

Following Gile's (2005) research, this paper defines an encoded unit as the set of linguistic and non-linguistic signs and a system of techniques that is used for information fixation for that information to be remembered and re-expressed in another language. Presently, cognitive research states that the process of perception of a linguistic and non-linguistic unit has a lot in common. In the case of a non-linguistic unit, the separate characteristics such as shape or size are processed simultaneously by different mental structures. After having been processed, the visual elements of information are combined into a 
single image. This distributed representation explains why a person recognizes an object despite the distance between them, the missing elements or poor visibility. The mental structure will compare what a person sees with a representation that was created in the mind based on the similar image.

Despite the formal characteristics of a word and the comparative complicity of the symbol, I state that the words and symbols have much in common. A word is a specific object which is identified by the analysis of a set of strokes, curves, and angles between them, the configurations of which are limited. Perceiving letters in a way is similar to perceiving a symbol. The stokes and curves that create a linguistic sign trigger the activation of particular neurons. To perceive the visual linguistic and non-linguistic information humans use the same mechanisms for analyzing and classifying both words and symbols.

This paper argues that although there are similarities between the mental processes in word and symbol perception, the understanding of a linguistic unit does not equal the understanding of a non-linguistic unit. Perceiving a symbol, the conceptual level is activated, the lexical representation is used only when a person needs to describe the meaning of a symbol or the situation where it can be used. Controversially, when perceiving linguistic contents, the lexical level is activated first, and the conceptual representation is created only after that.

From a semiotic viewpoint, the note-taking system is considered as a collection of linguistic and non-linguistic signs that hint at the cognitive processes required to verbalize a meaning behind them (Albl-Mikasa 2017; Stecconi 2007; Taylor-Bouladon 2001). These symbols can be linguistic and non-linguistic, and act as a set of hints for speech reproduction. The interpreter analyses the source speech selects the notation items and notation method (making a word into a symbol) on the listening phase (Gillies 2005) and reproduces the speech by reading from notes on the production phase (Gillies 2005).

In other words, the interpreters' notes may contain linguistic units the meaning of which is drawn from its semantics, linguistic units which serve as a symbolic representation of a certain fragment of the source speech and nonlinguistic units, which are symbolic cues serve to aid interpreter's memory. In other words, this research falls in the line with Sassure's (1857-1913) conclusions which state that both linguistic and non-linguistic units can be of symbolic nature.

The aim of the present research is to provide the grounds for a different approach to note-taking research in consecutive interpretation and by doing so 
to present some possible solutions which would be based on the interpreter's understanding of the notes they write.

The research questions of this study are:

(RQ1) What is included in interpreters' notes?

and

(RQ2) What defines a linguistic unit and a symbol in interpreters' notes?

The experiment presented in this paper provides a description of cases in which linguistic notation units prove to be the units of a symbolic nature.

\section{Methodology}

For this paper, I carried out a study with the native Japanese speaking undergraduate students (see Table 1 below) who volunteered to participate in the experiment as their extra-curriculum activity. The study was carried out in Japan, in a private university in Tokyo. The subjects were tasked to do an English to Japanese consecutive interpretation of an approximately seven-minute English speech.

It is genuinely not advisable to use interpreter trainees as subjects in consecutive interstation experiments (Dam 2004). However, recruiting interpreter trainees as subjects does not interfere with the current goal, although I have to admit that pursuing more concrete results it would be beneficial to carry out the experiments with professional interpreters.

The characteristics of the speech used in the experiment are presented in Table 2 below.

The experiment consisted of consecutive interpretation and the interview in which the subjects were asked to explain the meaning of each notation unit and the way they "read" their notes in consecutive interpretation. The subjects were examined one by one, the interview followed the interpretation test consecutively. By the end of the experiment, I obtained two audio records from the consecutive interpretation and an interview with each subject and an original of hand-written interpreters' notes. 
Table 1. The subjects. For all the subjects, Program term $=2$ years and A-language $=$ Japanese.

\begin{tabular}{|c|c|c|c|c|c|c|}
\hline 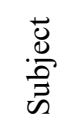 & $\begin{array}{l}\text { Interpreter } \\
\text { training program }\end{array}$ & $\begin{array}{l}\text { Status in pro- } \\
\text { gram at time of } \\
\text { experiment }\end{array}$ & B-language & & Age & $\begin{array}{l}\text { Hrs of train- } \\
\text { ing at time of } \\
\text { experiment }\end{array}$ \\
\hline 1 & \multirow{4}{*}{$\begin{array}{l}2 \text { consecutive } \\
\text { interpretation } \\
\text { practice seminars } \\
\text { (with no predeter- } \\
\text { mined language } \\
\text { combination), } \\
1 \text { theoretical } \\
\text { seminar }\end{array}$} & \multirow{4}{*}{$\begin{array}{l}\text { currently } \\
\text { enrolled }\end{array}$} & $\begin{array}{l}\text { Proficient } \\
\text { user }\end{array}$ & $\begin{array}{l}\text { TOEFL } \\
\text { iBT } 101\end{array}$ & 23 & 135 \\
\hline 2 & & & $\begin{array}{l}\text { Proficient } \\
\text { user }\end{array}$ & $\begin{array}{l}\text { TOEIC } \\
985 \\
\end{array}$ & 23 & 135 \\
\hline 3 & & & $\begin{array}{l}\text { Independ- } \\
\text { ent user }\end{array}$ & $\begin{array}{l}\text { TOEIC } \\
880\end{array}$ & 23 & 135 \\
\hline 4 & & & $\begin{array}{l}\text { Proficient } \\
\text { user }\end{array}$ & $\begin{array}{l}\text { TOEFL } \\
\text { iBT } 100\end{array}$ & 23 & 135 \\
\hline 5 & \multirow{6}{*}{$\begin{array}{l}2 \text { consecutive } \\
\text { interpretation } \\
\text { practice seminars } \\
(\mathrm{E} \rightarrow \mathrm{J}, \mathrm{J} \rightarrow \mathrm{E}) \text {, } \\
1 \text { theoretical } \\
\text { seminar }\end{array}$} & \multirow{6}{*}{$\begin{array}{l}\text { a week since } \\
\text { completion }\end{array}$} & $\begin{array}{l}\text { Proficient } \\
\text { user }\end{array}$ & $\begin{array}{l}\text { TOEIC } \\
945 \\
\end{array}$ & 25 & 180 \\
\hline 6 & & & $\begin{array}{l}\text { Proficient } \\
\text { user }\end{array}$ & $\begin{array}{l}\text { TOEIC } \\
970\end{array}$ & 23 & 180 \\
\hline 7 & & & $\begin{array}{l}\text { Proficient } \\
\text { user }\end{array}$ & $\begin{array}{l}\text { TOEFL } \\
\text { iBT } 102\end{array}$ & 24 & 180 \\
\hline 8 & & & $\begin{array}{l}\text { Proficient } \\
\text { user }\end{array}$ & $\begin{array}{l}\text { TOEFL } \\
\text { iBT } 110\end{array}$ & 23 & 180 \\
\hline 9 & & & $\begin{array}{l}\text { Proficient } \\
\text { user }\end{array}$ & $\begin{array}{l}\text { TOEIC } \\
970\end{array}$ & 24 & 180 \\
\hline 10 & & & $\begin{array}{l}\text { Proficient } \\
\text { user }\end{array}$ & $\begin{array}{l}\text { TOEIC } \\
975\end{array}$ & 24 & 180 \\
\hline
\end{tabular}

Table 2. The English-language speech.

\begin{tabular}{ll}
\hline Measure & Value \\
\hline Duration & 6 mins $58 \mathrm{sec}$ \\
Length & 3022 words \\
Speed & 120 words per minute \\
Number of fragments & 15 fragments \\
Duration of each fragment & $25-30 \mathrm{sec}$ \\
Information density & 2.3 \\
\hline
\end{tabular}


The analysis was carried out in two stages. First, I studied and analyzed all the hand-written notes. To avoid introducing an ad hoc classification, the notes were calculated and classified into "linguistic" and "non-linguistic" units. Albl-Mikasa's (2017) observations hint on the possibility of an interpreter treating their linguistic units in the notes as symbols. "LD" for "ladies and gentlemen", or "ladies" for "ladies and gentlemen" may serve as a good example. At first glance, these examples seem to be language-based notes which in some cases are attributed to abbreviation, or paraphrase, or even shortenings. But they also may be of symbolic nature, in other words, the meaning might be drawn not from the semantics which these words initially possess, but from graphical stylistic or even the mere fact that this unit is converted into writing. Human memory alone would be insufficient for speech reproduction because outside resources play an important part in memory function (Stockwell 2014). The interpreters' notes act as an outside mental resource that does not necessarily follow the conventional rules of writing in a language.

The second step was translating and coding the interviews. Initially, the interviews were planned to be carried out in the English language. However, all the subjects were using both English and Japanese during the interview, so I had to translate the Japanese parts of the conversation into the English language. The interviews were supposed to shed light on how the interpreters perceive their notes. The subjects were tasked to comment on the meaning and the writing technique of each notation unit they had written. The responses and comments were analyzed thematically and coded into a number of categories such as "language based", "language driven", "language assisted", "language oriented" and "symbol". These categories emerged during the analysis. Some examples and explanations of these categories are presented in Table 3.

Borrowing the classification of the above-mentioned interpreter training materials, the Symbol, Language oriented notes and Language driven notes can be attributed to the "symbols" category. If the Symbol category operates abstractions, then the Language Oriented note and the Language Driven note categories act like an ad hoc meta language or stenography with its lexical equivalent attached to every symbol. In other words, there is a linguistic component in Language Oriented notes which according to interpreter training literature should be considered as symbolic. On the other hand, the Language Based notes and Language Assisted notes category seems purely linguistic. However, the symbolic nature of the Language Assisted notes should be recognized as they consist of shortenings and abbreviations which are not perceived as incomplete lexical units. Rather they represent symbolic cues in 
Table 3. Note categories.

\begin{tabular}{|c|c|c|c|}
\hline Category & Explanation & $\begin{array}{l}\text { Example from the } \\
\text { interview }\end{array}$ & $\begin{array}{l}\text { Example from inter- } \\
\text { preters' notes }\end{array}$ \\
\hline Symbol & $\begin{array}{l}\text { A visual representation } \\
\text { of a situation or state } \\
\text { with no connection to } \\
\text { the words that describe } \\
\text { this situation or state }\end{array}$ & $\begin{array}{l}\text { A: It is convenient } \\
\text { for me to use emoji }\end{array}$ & ;) \\
\hline $\begin{array}{l}\text { Language } \\
\text { based notes }\end{array}$ & $\begin{array}{l}\text { Full words that are } \\
\text { read in a conventional } \\
\text { way during the } \\
\text { interpretation }\end{array}$ & $\begin{array}{l}\text { Q: ok, and what does } \\
\text { this character here } \\
\text { mean? } \\
\text { A: dentou for } \\
\text { traditional }\end{array}$ & $\begin{array}{l}\text { 伝統 dentou } \\
\text { (tradition/traditional) }\end{array}$ \\
\hline $\begin{array}{l}\text { Language } \\
\text { driven notes }\end{array}$ & $\begin{array}{l}\text { Symbolic units with } \\
\text { their culture-specific } \\
\text { semantics in the target } \\
\text { or the source language }\end{array}$ & $\begin{array}{l}\text { Q: why did you } \\
\text { write batsu and } \\
\text { fusoku } \text { [shortage]? } \\
\text { A: he said something } \\
\text { like no shortage... } \\
\text { Q: no shortage of } \\
\text { bad news A: yes and } \\
\text { batsu in Japanese } \\
\text { means no }\end{array}$ & $\begin{array}{l}\text { X batsu } \\
\text { (a symbol with a } \\
\text { meaning 'wrong' in } \\
\text { Japanese; not a } \\
\text { character) }\end{array}$ \\
\hline $\begin{array}{l}\text { Language } \\
\text { assisted } \\
\text { notes }\end{array}$ & $\begin{array}{l}\text { The notation units } \\
\text { were shortened, } \\
\text { abbreviated or other- } \\
\text { wise manipulated by } \\
\text { the interpreter. The } \\
\text { original word could be } \\
\text { easily reconstructed } \\
\text { based on its fragment } \\
\text { and semantics }\end{array}$ & $\begin{array}{l}\text { A: Sometimes } \\
\text { English is easier to } \\
\text { write, but sometimes } \\
\text { kanji [characters] is } \\
\text { easier. For example, } \\
\text { this mon is mondai } \\
\text { no mon. English is } \\
\text { longer }\end{array}$ & $\begin{array}{l}\text { 問 mon } \\
\text { (the first of the two } \\
\text { characters which form } \\
\text { the word 'problem') }\end{array}$ \\
\hline $\begin{array}{l}\text { Language } \\
\text { oriented } \\
\text { notes }\end{array}$ & $\begin{array}{l}\text { A representation of the } \\
\text { conceptual meaning of } \\
\text { a word }\end{array}$ & $\begin{array}{l}\text { A: This is the picture } \\
\text { of a coin. I use this } \\
\text { sign when I write } \\
\text { about money }\end{array}$ & $\begin{array}{l}\Theta \\
\text { (the symbol resem- } \\
\text { bles an old Japanese } \\
\text { coin) }\end{array}$ \\
\hline
\end{tabular}

which the form of the unit hints on the semantics of the original word. All in all, this research reveals that there is a linguistic component in symbolic notes and a symbolic component in linguistic notes. 
The data analysis concluded with a calculation of symbols, language based notes (LB), language driven notes (LD), language assisted notes (LA) and language oriented notes (LO) in linguistic and non-linguistic units.

\section{Results}

The present paper shows that the proportion of linguistic and non-linguistic units is unequal and bends towards linguistic units. Which, once again, at first glance make the researcher turn to classifying the contents of interpreters' notes into the controversial categories found in the teaching materials (Fig. 4).

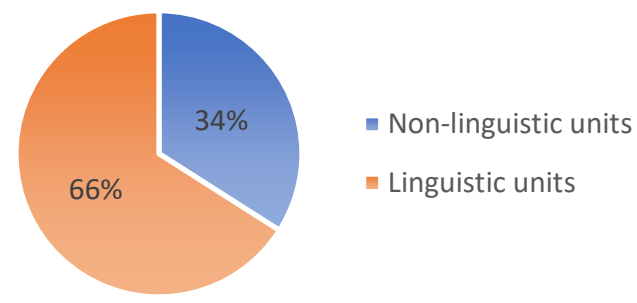

Figure 4. The proportion of linguistic and non-linguistic units in interpreters' notes.

However, my analysis shows that the contents of interpreters' notes does not necessarily depend on the types of interpreters' notes described in interpreter training literature (Fig. 5).

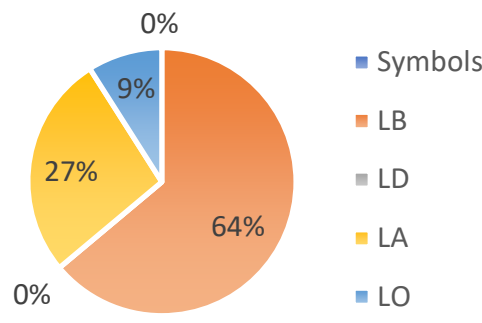

Figure 5. The proportion of Symbols, LB, LD, LA and LO in linguistic notes. 
Figure 5 demonstrates that there are notes of a symbolic nature in linguistic notes. These notes are abbreviations, shortenings and paraphrases the semantics of which, according to the interview, did not play any substantial role in reproducing. Rather they hinted on a certain situation in the original speech.

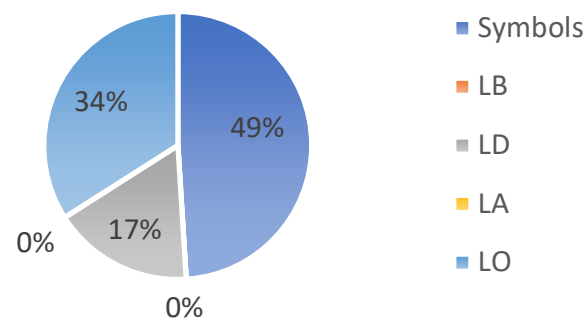

Figure 6. The proportion of Symbols, LB, LD, LA and LO in non-linguistic notes.

Figure 6, in turn, demonstrates the presence of a linguistic component in the symbols. Although these two Figures provide a new perspective on the contents of interpreters' notes, the final description of the contents of interpreters' notes and the debates on the nature of the language choice in interprets' notes is yet to be done.

\section{Discussion}

\subsection{The contents of interpreters' notes}

So far, the most common categories that were the subject of scrutiny in notetaking research were the shortenings, abbreviations, paraphrases, symbols and language units. Interpreters' notes incorporate both linguistic and non-linguistic units. Some of them are of a symbolic nature despite being linguistic units. On the other hand, there are always language-based units that cannot be attributed to symbols. The results of this paper agree with a German researcher Albl-Mikasa who highlights the notation language as a written language with an emphasis that notation language is mainly composed of symbolic signs: 
"The etymologically natural coexistence of symbolic and pictographic or iconic signs is typical also of NL [notation language]" (Albl-Mikasa 2017: 80). Citing Ilg (1980), Albl-Mikasa argues that note-taking is made with the exploitation of natural language through reduction, simplification, adaptation and iconization processes: "basic notation lexemes are either taken from existing signs... or designed on the basis of notation specific principals such as high association pictographication, abbreviation, or use of initials and various alphabets" (Albl-Mikasa 2017: 81). Note-taking in this context is seen as an individually customized form of a written language.

My research shows that only LB units can undoubtedly be attributed to purely linguistic contents. Other notation units are language signs and symbols. According to the respondents, without referring to a word's semantics they make an interpreter-reader skip the lexical level, thus providing direct access to the conceptual representation. In Section 3 a distinction between human perception of symbols and the linguistic unit is given. As can be seen from the examples in Table 4, LB and LA units are perceived with the activation of the lexical level. LD and LO units, on the contrary, are first perceived as conceptual representations. They are verbalized when the interpreter describes the meaning, the situation where they are used or the context of the original speech from which they are driven.

My viewpoint lies on the premises of a large number of studies in consecutive interpretation that were carried out with English and Asian languages: "Letters (graphemes) and words are clearly linguistic units and, in the written mode, are complemented by the ... ideographic and logographic signs to form a language system for written communication" (Albl-Mikasa 2017: 79). With a wave of research on English-Chinese and English-Japanese interpretation, the interpreters' notes that contained characters were introduced in the field of consecutive interpretation. Chinese characters were introduced as a phoneticindependent unified writing system of logographic signs (Strohner 2000). The Japanese writing system is a combination of logographic units with syllabic signs (Rickheit \& Strohner 1993), and Korean alphabetic signs are often used alongside Chinese-based word signs (Albl-Mikasa 2017). Chen (2017), Liu (2009), Setton (2014), Wang et al. (2010) investigated the use of characters in interpreters' notes and reported on using characters as shortened words and as iconic signs that hint on a certain meaning. Characters in the notes are not constrained by the conventional use in a written language (Liu 2009). For example, Japanese researcher Komatsu (2005) observed that the characters in the notes of native Japanese speaking interpreters are almost never followed by 
Table 4. Examples of interpreters' notes and comments made during the interview.

\begin{tabular}{|c|c|c|c|}
\hline Category & $\begin{array}{l}\text { Example from } \\
\text { interpreters' notes }\end{array}$ & Explanation & $\begin{array}{l}\text { Example from the inter- } \\
\text { view }\end{array}$ \\
\hline LA & 小 & $\begin{array}{l}\text { Japanese character mean- } \\
\text { ing small or little is used } \\
\text { in the notes in the mean- } \\
\text { ing of 'mini' in the word } \\
\text { combination mini tornado. }\end{array}$ & $\begin{array}{l}\text { Q: I see, is this little? } \\
\text { A: Yes, I wrote it for } \\
\text { mini }\end{array}$ \\
\hline LA & $\begin{array}{c}\text { 米 } \\
\text { 日 }\end{array}$ & $\begin{array}{l}\text { 米 character alone means } \\
\text { 'rice' and reads kome, } \\
\text { together with the character } \\
\text { with the meaning 'coun- } \\
\text { try' it designates 'Amer- } \\
\text { ica'. } \\
\text { The second character } \\
\text { reads as niti means 'day' } \\
\text { on its own, but it desig- } \\
\text { nates 'Japan' paired with } \\
\text { the character with the } \\
\text { meaning 'country'. }\end{array}$ & $\begin{array}{l}\text { Q: I see you write kome } \\
\text { for America } \\
\text { A: Yes, that's how we } \\
\text { usually write it. And niti } \\
\text { for Japan }\end{array}$ \\
\hline LB & 早い/速い & $\begin{array}{l}\text { Both characters read as } \\
\text { hayai. The first one means } \\
\text { 'early' and the second one } \\
\text { means 'quick'. The speech } \\
\text { mentioned a hand dryer } \\
\text { that quickly dries your } \\
\text { hands, so the word } \\
\text { 'quickly' should have } \\
\text { been used. }\end{array}$ & $\begin{array}{l}\text { Q: Did you notice you } \\
\text { have a spelling mistake } \\
\text { A: Where? } \\
\text { Q: Hayai instead of } \\
\text { hayai } \\
\text { A: Yes. Really, I didn't } \\
\text { notice it. I thought I } \\
\text { wrote the correct word }\end{array}$ \\
\hline LB & ものを増やす & $\begin{array}{l}\text { Literally translates as 'in- } \\
\text { crease different things' } \\
\text { and reads as mono wo } \\
\text { fuyasu. The subject mis- } \\
\text { heard the speaker who } \\
\text { said increase staff and } \\
\text { wrote increase stuff in the } \\
\text { Japanese language. The } \\
\text { phrase would have been } \\
\text { different in the Japanese } \\
\text { language had the subject } \\
\text { heard correctly. }\end{array}$ & $\begin{array}{l}\text { A: I didn't understand } \\
\text { stuff. Mono wo fuyasu. I } \\
\text { didn't hear staff, I heard } \\
\text { stuff... }\end{array}$ \\
\hline
\end{tabular}




\begin{tabular}{|c|c|c|c|}
\hline LD & $x$ & $\begin{array}{l}\text { As has been said in Table } \\
3, X \text { is a symbol for } \\
\text { 'wrong', 'no' and every- } \\
\text { thing that is negative in } \\
\text { Japan. It is used widely in } \\
\text { Japanese SNS communi- } \\
\text { cation. }\end{array}$ & $\begin{array}{l}\text { A: There is a batsu and } \\
\text { design and that means } \\
\text { that design is not effi- } \\
\text { cient }\end{array}$ \\
\hline LO & & $\begin{array}{l}\text { The subject produced the } \\
\text { visual representation of } \\
\text { the words in the original } \\
\text { speech. }\end{array}$ & $\begin{array}{l}\text { Q: Why did draw the tor- } \\
\text { nado } \\
\text { A: I was listening to the } \\
\text { speech... I drew this } \\
\text { when he said mini tor- } \\
\text { nado }\end{array}$ \\
\hline
\end{tabular}

the Japanese syllabic alphabet in the context where it should be complemented by the signs of Japanese syllabic alphabet in conventional writing. This observation confirmed that native Chinese, Japanese speaking interpreters can perceive characters both as words and symbols.

Emphasizing notation language as an individual language, Albl-Mikasa explores how language-based and symbolic units (in a broader sense that is not limited to characters) are used in interpreters' notes. One of the results of her experiment is that "NT [note taking] processing induces not only a change in languages, but brings about alternations between natural and artificial languages, and spoken and written modes as well as an element of "Chinese whispers"' (Albl-Mikasa 2017:110). This citation shows the fuzziness of the boundaries between symbolic and language-based units in interpreters' notes. That be the case, can a line be drawn between a linguistic unit and a symbolic unit in interpreters' notes?

\subsection{What defines a linguistic unit and a symbol in interpreters' notes}

In Peirce and Morris's (Petrilli 2004) viewpoint any object can become a sign if it is engaged in a certain relationship outside the object. Any sign represents something. The relationship between the sign and the object it represents is the meaning of this sign. Semiotics describes three main types of sign meanings. 
The meaning of the signs is drawn from either the sign and the object that is represented with this sign (referential), the sign and a person who uses it (pragmatic), and between the signs of a single system (linguistic meaning). In terms of referential meaning, interpreters' notes should be compared with the source speech and the yet to be voiced target speech in the interpreter's mind. However, all the interpreter training material advocates for the ideas and not words to be noted. In her autobiographical essay Sekiya (2013) writes that she does not perceive the source speech as a set of sentences, she treats it as a set of ideas. Seleskovitch (1975) was one of the pioneers who carried out an analytical study in the interpretation field. She describes note des mots 'noting words' as opposed to notes d'idées 'noting ideas'. In her opinion, the interpreter basically adopts noting ideas mode and changes it to noting words when noting numerical data, terms, names, etc. In the late 1970s, Lederer conducted her empirical study which resulted in the concept of l'unité de sens 'the units of meaning': "Units of meaning are the synthesis of a number of words present in short term memory and are associated with previous cognitive experiences or recollections" (Seleskovitch 1986: 78). In other words, there is a relationship between interpreters' notes and the source and target speeches, however, this relationship should not be anticipated as a word for word copying of the source speech, or prompting of the target speech. Unlike language signs, the interpreters' notes are created for the sole purpose of information storage. These notes function as an ad hoc memory enhancement and they are said to be difficult to read from when the interpretation is over. Since the beginning of note-taking studies and in present-day research the interpreters' notes demonstrate an individual encoding system amongst other features.

The way the interpreter handles their notes, however, is within the general understanding of semiosis and sign interpretation, which brings us to the second meaning - pragmatic. The categories in question have already been described from the pragmatic perspective in Tables 3 and 4. This perspective allows speculating on the contents of interpreters' notes from the interpreter's position. For many years the interpreter's vision of their own notes has been neglected in note-taking research. This paper attempted to reveal the potential of carrying out the research from a human-centered approach.

From the perspective of linguistic meaning, the signs do not belong to a single system. They may be classified as linguistic and non-linguistic notes, as demonstrated in this paper. However, their symbolic and linguistic nature that lies beyond the shell of linguistic and non-linguistic unites calls for a different 
categorisation in which all nuances of interpreters' notes written in different word languages are taken into the account.

\section{Conclusion and perspectives}

The present research goes in the line with the latest tendencies in the field and aims to provide a description of the contents of interpreters' notes written in the course of consecutive interpretation. As mentioned in the sections above, there are still many blind spots in note-taking research. It is, therefore, worthwhile to start the note-taking research anew and study how the interpreters take their notes in an authentic learning environment. This paper reconstructed the consecutive interpretation environment by carrying out the interpretation experiment and inquired into the process of note-taking by carrying out an interview.

The results showed the presence of notes of symbolic nature in both linguistic and non-linguistic notes and the notes with the linguistic component inside linguistic and non-linguistic note categories. The results of this paper call for reconsidering the contents of interpreters' notes which is described in the consecutive interpreter teaching material.

One of the possible solutions is to address the issue from the viewpoint of semiotics. Although there are few studies in which the interpreters' notes were explicitly investigated from a semiotic viewpoint, a hint on that the interpreters' notes represent a sign system is contained in a large number of research. This idea is also drawn from the description of Seleskovitch and Lederer's (1986) deverbalisation and picked up by Gillies (2005) in his description of interpreters' notes as concepts.

Unfortunately, an interview alone is insufficient in tracking concepts. First, the interviewee tends to forget all the information that was in their heads when they noted a certain segment. Second, there is always a high degree of subjectivism in the interview, because the subject speaks about their ideas of what happened and not about what really was happening. An interview, however, is a good tool to draw a picture of a research issue and study all the aspects of the issue. I recommend the next step to be the implementation of eyetracking technologies into consecutive interpretation experiments to see how the subjects perceived their notes on the writing stage and on the reading stage and compare the obtained data with the interview. This combination will shed even more light on the nature of interpreters' notes and will serve as an 
empirical basis for categorization. Similar research has already been carried out with Chen (2018) pioneering in the field. However, the research of the same technical nature has yet to address the question of the contents of interpreters' notes in consecutive interpretation.

\section{References}

Ahrens, B. 2005. Prosodic phenomena in simultaneous interpreting: A conceptual approach and its practical applications. Interpreting 7(1). 51-76.

Albl-Mikasa, M. 2017. An empirical study on consecutive notes and notetaking. In Y. Someya (ed.), Consecutive notetaking and interpreter training. London \& New York: Routledge. 71-117.

Alexieva, B. 1993. On teaching note-taking in consecutive interpreting. In C. Dollerup \& A. Lindegaard (eds.), Teaching translation and interpreting 2: Insights, aims, visions. Amsterdam/Philadelphia: John Benjamins. 199-206.

Chen, S. 2017. Note-taking in consecutive interpreting: New data from pen recording. International Journal for Translation and Interpreting Research 9(1). 4-23.

Chen., S. 2018. Exploring the process of note-taking and consecutive interpreting: a pen-eye-voice approach towards cognitive load. The Interpreter and Translator Trainer 12(4). 1-2.

Chernov, G. 2004. Inference and anticipation in simultaneous interpreting: A probability-prediction model. Amsterdam \& Philadelphia: John Benjamins.

Crèpin, F. \& M. Loridon. 1992. Français, méthodes et techniques, édition 1992. Classes des lycées, livre de l'élève. France: Nathan.

Dam, H.V. 2007. What makes interpreters' notes efficient? Features of (non-)efficiency in interpreters' notes for consecutive. In Y. Gambier et al. (eds.), Doubts and directions in translation studies: Selected contributions from the EST Congress, Lisbon 2004. Amsterdam \& Philadelphia: John Benjamins. 183-197.

Dam, H.V. 2004. Interpreters' notes: on the choice of form and language. In G. Hansen, K. Malmjkaeer \&. D. Gile (eds.), Interpreting 6(1). Amsterdam \& Philadelphia: John Benjamins. 3-17.

Gillies, A. 2005. Note-taking for consecutive interpreting: A short course. New York/ Oxford: Routledge.

Gile, D. 1995. Basic concepts and models for interpreter and translator training. Amsterdam \& Philadelphia: John Benjamins.

Herbert, J. 1952. Manuel de l'interprete: comment on deviant interprete de conferernces. Genève: Librairie de l'Université Georg.

Ilg, G. 1988. La prise de notes en interpretation consecutive. Une orientation generale. Paralleles 9. 9-13.

Jones, R. 2002. Conference interpreting explained. New York \& Oxford: Routledge. Komatsu, T. 2005. Tsu:yaku no gijutsu [The interpreters' skills]. Tokyo: Kenkyusya

Liu, M. \& Y.H. Chiu. 2009. Assessing source material difficulty for consecutive interpreting: Quantifiable measures and holistic judgment. Interpreting 11(2). 244 266. 
Matyssek, H. 1989. Handbuch der Notizentechnik für Dolmetscher. Ein Weg zur sprachunabhängige Notation. Heidelberg: Julius Groos.

Minyar-Beloruchev, R. 1980. Obshchaya teoriya perevoda $i$ ustnyi perevod [The theory of translation and interpretation]. Moscow: Voen. izd-vo Ministerstva oborony.

Obst, H. 2010. White House interpreter: The art of interpretation. Bloomington: Author House.

Petrilli, S. 2004. From pragmatic philosophy to behavioral semiotics: Charles W. Morris after Charles S. Peirce. Semiotica 148. 277-315.

Rickheit, G. \& H. Strohner. 1993. Grundlagen der kognitiven Sprachverarbeitung. Modelle, Methoden, Ergebnisse. Tübingen: Francke.

Rozan, J.F. 1956. La prise de notes en interprétation consécutive. Genève: Librairie de l'Université Georg.

Sekiya, E. 2016. Douji tsuyakusya no atama no naka [The contents of interpreter's head]. Tokyo: Shodensha.

Seleskovitch, D. 1975. Language, langues et memorie. Etude de la prise de notes en interpretation consecutive. Paris: Minard Letters Modernes.

Seleskovitch, D. 1986. The teaching of conference interpreting in the course of the last 50 years. In I. Kruz \& M. Bowen (eds.), Interpreting 4(1/2). Amsterdam \& Philadelphia: John Benjamins. 55-66.

Setton, R. \& A. Dawrant. 2016. Conference interpreting: Complete course. Amsterdam \& Philadelphia: John Benjamins.

Someya, Y. 2017. An empirical study on consecutive notes and notetaking. In Y. Someya (ed.), Consecutive notetaking and interpreter training. London \& New York: Routledge. 147-239

Stecconi, U. 2009. Semiotics. In M. Baker \& G. Saldanha (eds.), Routledge encyclopedia of translation studies. London \& New York: Routledge. 260-263.

Stockwell, G. 2014. Exploring theory in computer-assisted language learning. In X. Deng \& R. Seow (eds.), Alternative pedagogies in the English language and communication classroom: Selected Papers from the Fourth CELC Symposium for English Language Teachers. Singapore: Centre for English Language Communication, National University of Singapore. 25-30.

Strohner, H. 2000. Kognitive Voraussetzungen: Wissenssysteme - Wissensstrukturen - Gedächtnis. In K. Brinker, G. Antos, W. Heinemann \& S.F. Sager (eds.), Text und Gesprächslinguistik: Ein internationales Handbuch zeitgenössischer Forschung. Berlin: de Gruyter. 261-274.

Szabo, C. 2006. Language choice in note-taking for consecutive interpreting. Interpreting $8(2)$. 129-147.

Taylor-Bouladon, V. \& D. Barrett. 2001. Conference interpreting: Principles and practice. Australia: BookSurge Publishing.

Wang, W., D. Zhou \& L. Wang. 2010. An empirical study of note-taking characteristics and output quality in interpreting. Foreign Language World 4. 9-18. 
Corresponding author:

Anna Sasaki

English Language and Literature Department

Seisen University

Graduate School of International Culture and Communication

Waseda University

$\mathrm{m} @$ dranna.net 